
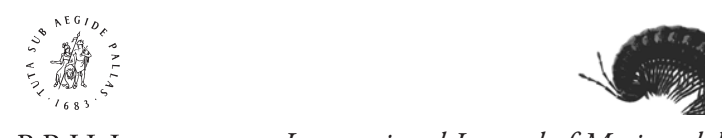

PENSOF.

B R I L L

International Journal of Myriapodology 3 (2010) 169-179

Sofia-Moscow

\title{
Spirostreptid millipeds from the Imatong Mountains, Sudan
}

\author{
Richard L. Hoffman \\ Virginia Museum of Natural History, Martinsville, Virginia 24112, USA. \\ E-mail: richard.hoffman@vmnh.virginia.gov
}

\begin{abstract}
Two species of Spirostreptidae from the Imatong Mountains in southernmost Sudan are described and figured. The new genus and species Helictostreptus attemsi is based on two specimens from Gilo, the taxon is distinctive for the doubly spiraled coil of the gonopod telopodite, unknown in other African members of the family. Some structural details and gonopopd drawings are provided for Tibiozus robustus Attems, 1950 (previously known only from Gondokoro on the White Nile), on the basis of a male from Talanga. The nominal subspecies T. r. pharaonicus Attems, 1950, is considered to be a strict synonym of robustus.
\end{abstract}

\section{Key words}

Diplopoda, Spirostreptidae, Tibiozus, Helictostreptus, new species, Sudan, Imatong Mountains

\section{Introduction}

The monotonous flat plains of southern Sudan are broken dramatically near the border with Uganda by several impressive massifs, one of which, the Imatong Mountains, contains (at Mount Kinyeti, 10,456 ft./3187 m) the highest elevation of the country. Invested by tracts of tropical montane rainforest, these ranges invite interest from a biogeographical perspective, and some biotic elements (e.g., plants, birds) have already received considerable attention. But knowledge of the soil fauna remains rudimentary, and political instability in recent years has discouraged the investigations needed to abate this area of ignorance. In common with most other regions of the world, the Imatongs are undergoing degradation (forest loss, erosion) as the result of burgeoning human populations, with the attendant urgency for biotic inventory while some remnants of the original environment remain.

In 1980, a Danish botanical-herpetological expedition visited the Imatong Mountains. Among the material of soil arthropods obtained by this initiative are samples of 
two spirostreptid millipeds which were transmitted to me by Prof. Dr. Henrik Enghoff to whom I extend my appreciation for the opportunity of working with these interesting organisms.

\section{Taxonomy}

\section{Family Spirostreptidae}

\section{Helictostreptus, gen. nov.}

urn:lsid:zoobank.org:act:7DEA09D8-7356-46ED-8237-E79DCBC09663

Type species: Helictostreptus attemsi, sp. n.

Name: A neologism composed of the Greek elements heliktos (spiraled) and "-streptus" a combining form derived from Spirostreptus.

Diagnosis: Moderate-sized spirostreptids $(\varnothing 5-6 \mathrm{~mm})$ with smooth, glabrous, impunctate integument; small ocellaria (ca 40 ocelli); collum of males only slightly produced anteroventrad, with two lateral striae; psectromere of mandible with four distinct lobes and 10 pectinate lamellae, molar surface with subapical transverse groove; basal sclerite of gnathochilarium narrowed, separated from base of mentum; prosterna smooth, metasterna with median carina, metacoxal cavities closed; males with ventroapical pads on postfemora and tibiae; paraprocts without defined margins.

Coxae of first pair of legs of male coalesced, forming a compact syncoxa with reduced sternal elements, oral side with small field of stout setae near center laterally; prefemoral processes large, subtriangular.

Gonopods with large, elongated median sternal element; paracoxites of moderate size, set off by flexible joint from metacoxites, latter distinctly curved laterad, their apices thus widely separated; metaplica apically expanded, its anterior face produced laterally into a long acuminate lateral process and slightly reflexed proximad; lateral surface with short groove; posterior face with partially closed vertical groove. Proplica apically modified: strongly reflexed proximad into a large median, internally setose lobe subtending arculus region of telopodite. Telopodite with prominent, $180^{\circ}$ torsion and small, elongate antetorsal process from its base, posttorsion region broadened, coiled through two complete revolutions thence reflexed distad to level of torsus at which point a small laminate process originates; apex of telopodite slender, with small apical lobe.

Range: Known only from the type locality of the type species in southernmost Sudan, probably endemic to the Imatong Mountains.

Remarks: The doubly-spiralled coiling of the gonopod telopodite is the most immediately obvious feature of the genus, and calls to mind a similar configuration in the monotypic genus Dicyclostreptus endemic to French Guyana (Mauries 1976, Jeekel 2006). That this curious modification must be considered only as independently homoplasic in the two genera is evident from differences between them in form of the gonopod sternum and proplical apex, in absence of the antetorsal process in Dicyclos- 
treptus, and overall shape of the first legs of the male. The illustrations provided by both Mauriès (1975) and Jeekel (2006) suggest that either the telopodite lacks torsion, or that the three loops are actually the unconsolidated torsion itself, in which case not anatomically homologous with the condition in Helictostreptus. Resolution of this situation is obviously a matter of some importance.

Evolution of the spiraled condition is presumably a functional way to accommodate an elongated telopodite although the selective advantage accruing to such a necessity is not immediately obvious. It is carried to an extreme in the Brazilian genus Helicogonus (Verhoeff 1943) in which the posttorsal telopodite is greatly reduced in size and is tightly coiled into four or five loops. Again, in this case, other traits preclude a close relationship between Helicogonus and the other two genera mentioned here.

The apical modification of the proplica is not approximated in any spirostreptid known to me and is probably a fundamental distinction. The superficially similar condition developed in Doratogonus hamifer (Attems, 1950) and D. fallax (Attems, 1935) has a different anatomical origin lower on the proplical surface and homology seems very unlikely, the more so as there are no other gonopodal resemblences shared by Doratogonus and Helictostreptus.

\section{Helictostreptus attemsi, sp. n.}

urn:Isid:zoobank.org:act:C26531F5-F8FF-498D-8475-521F739DDC47

Figures 1-8.

Material: Male holotype (Zool. Mus. Copenhagen), from the Imatong Mountains at Gilo, 1900 m. (ca. 32.560E, 4.03N), East Equatoria Province, Sudan; 7-9 November 1980, E. Wederkinch leg. (ZMC Expedition).

Name: Commemorates the great contributions to Myriapodology of Carl Graf Attems-Petzenstein, who justly may be considered Nestor of the Spirostreptoidea: author of 73 of the generic names proposed in this group.

Diagnosis: With the characters of the genus.

Holotype: Adult male with 50 (including collum and epiproct) segments/rings, length ca $70 \mathrm{~mm}$ (broken, fragments curved), body nearly cylindrical, at midbody 5.5 $\mathrm{mm}$ in transverse diameter, $5.6 \mathrm{~mm}$ in vertical, width of collum $5.2 \mathrm{~mm}$.

Description: Coloration at present (15 years in alcohol) very dark brown (piceous) to nearly black, prozona whitish-gray with white irrorations, caudal margins of metazona metallic reddish-brown, front of head light reddish-brown with piceous interocular band; antennae and legs clear testaceous orange (probably reddish-orange in life).

Head smooth, convex, without special modifications, interantennal width $1.9 \mathrm{~mm}$, interocular width $1.8 \mathrm{~mm}$, ocellaria elongate-triangular, $1.3 \mathrm{~mm}$ in length, ocelli in six distinct series: $11-9-8-7-4-2=41$. Antennae $5 \mathrm{~mm}$ long, both 5 th and 6th articles with prominent transverse apical sensory pit.

Mandible (Fig. 2) and gnathochilarium (Fig. 3) as described under generic heading. 


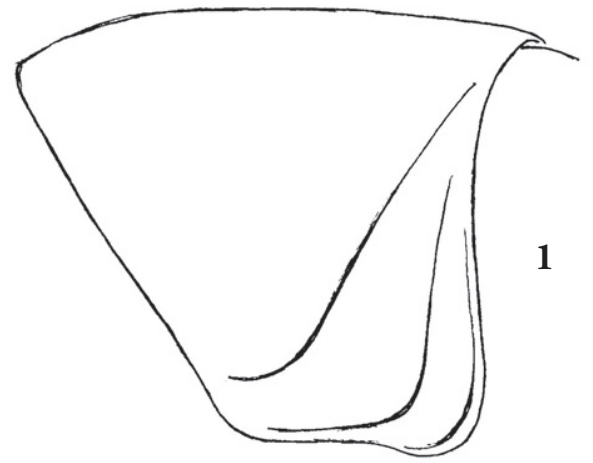

2

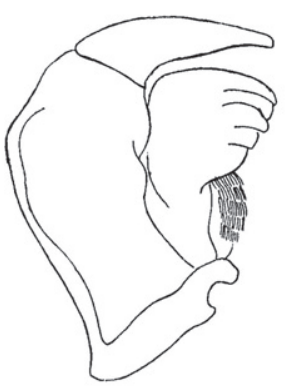

A
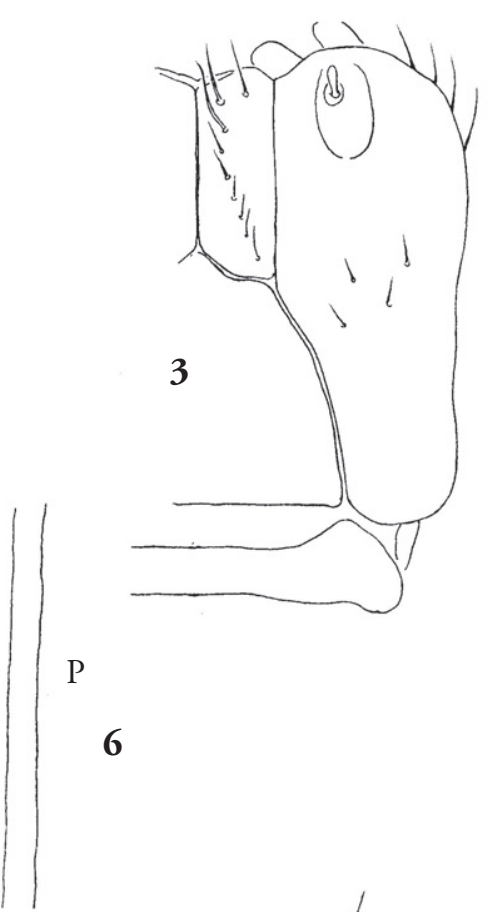

P

6
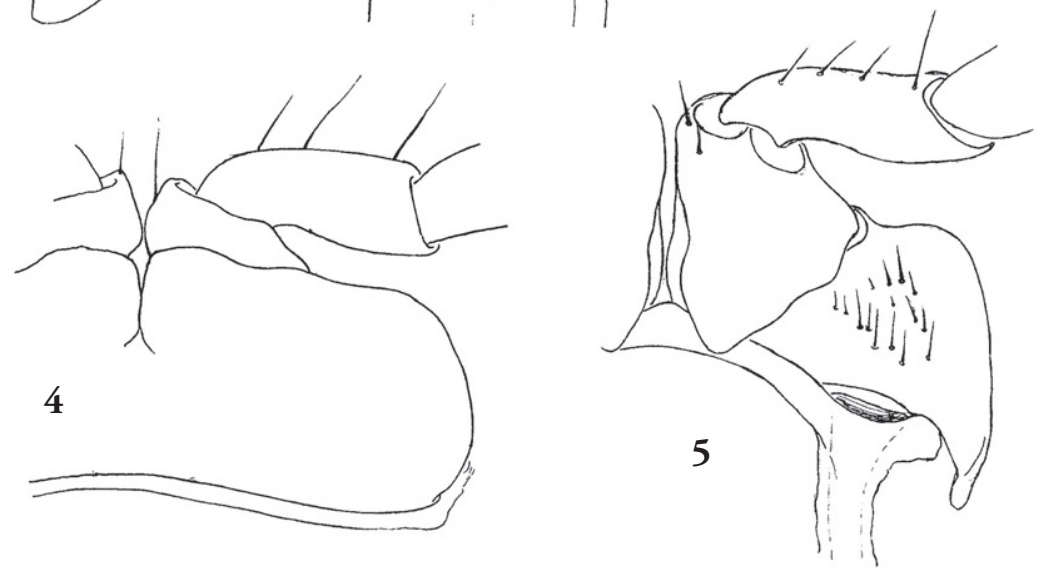

Figures 1-6. Helictostreptus attemsi, structural details. 1. Right side of collum. 2. Left mandible. 3. Left side of gnathochilarium. 4. Inner surface of midbody metazonum showing minute sigilla, dark pigmentation not indicated. 5. First pair of legs, oral aspect. 6. First pair of legs, aboral aspect.

Collum scarcely produced cephaloventrad, with one long oblique stria extending from level of eye to posterior margin, subtended by a short posterior branch, a shorter more ventral stria near front corner (Fig. 1). Surface of body segments smooth and polished, impunctate, metazona only slightly larger than prozona; lower sides with very fine longitudinal striae extending up nearly to level of ozopores, latter small but 

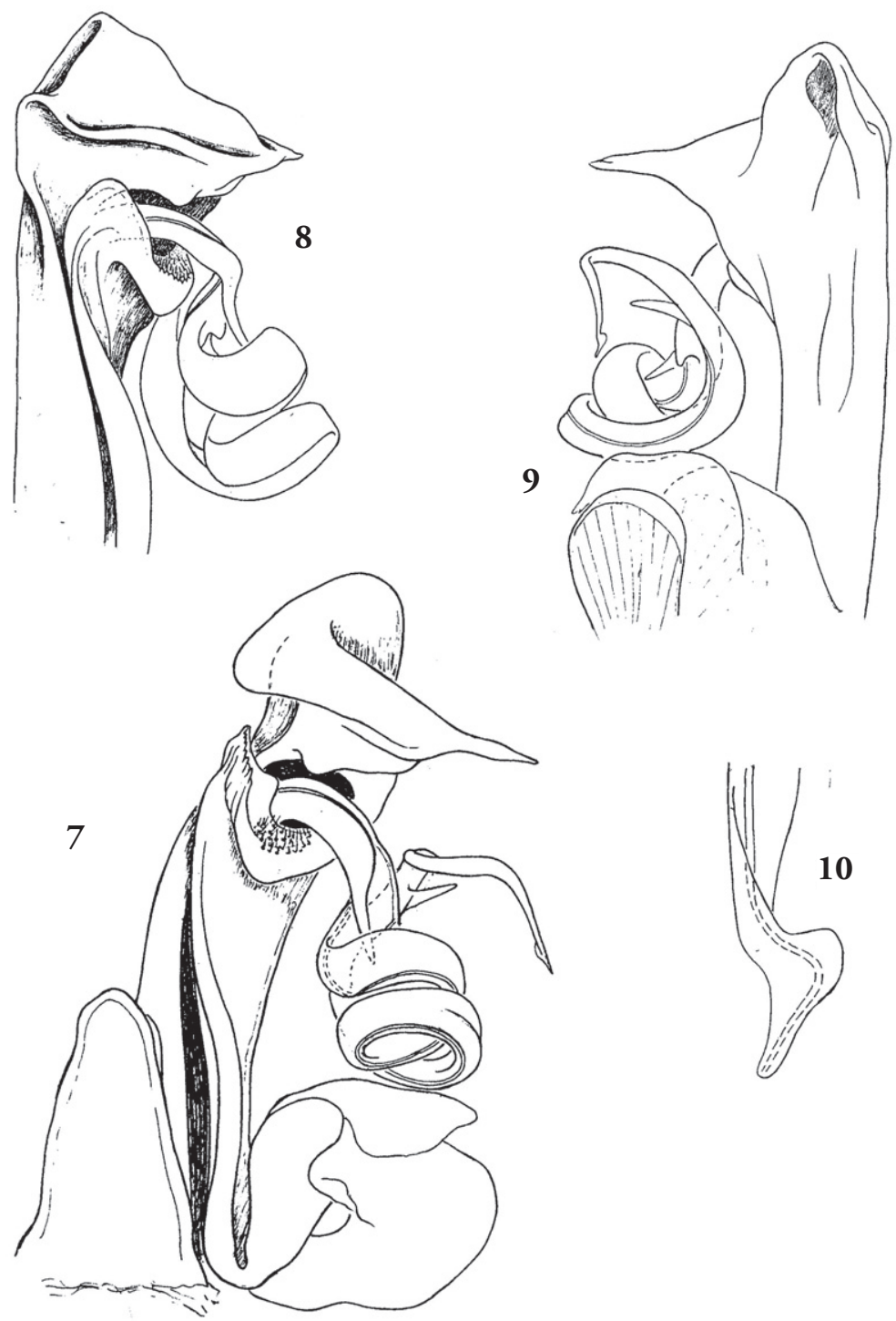

Figures 7-10. Helictostreptus attemsi, gonopod structure. 7. Right gonopod, oral aspect. 8. The same gonopod, distal half in an oblique cephalomedian aspect to show configuration of apical elements of proplica and metaplica. 9. The same gonopod, aboral aspect. 10. Apex of telopodite, greatly enlarged, showing terminal lobe.

distinct. Concentric striae of prozona very fine, about six in all, more closely spaced toward anterior edge. Sigilla very small, in a single row centered on dark endometatergal zone and only $1 / 20$ th its length (Fig. 4). Epiproct, paraprocts, and hypoproct of normal spirostreptid form, paraprocts only moderately convex, their distal edge without trace of marginal line, mesally in contact. 
Prosternal surface smooth, metasterna narrow with strong median carina, metacoxal cavities closed but posterior "bridge" very narrow, the inner lobes of pleuroterga in contact but not overlapping. Legs relatively long (ca $4.5 \mathrm{~mm}$ at midbody), apex of femora visible from above when legs extended laterad, podomeres smooth and glabrous, each with a single apical ventral seta except tarsi, with two large ventral setae and a smaller subapical posterior lateral. Coxae dissimilar: procoxae compressed, metacoxae thickened, their mesal surfaces flattened. Claws nearly half length of tarsi. Postfemora and tibiae with apicoventral pads visible on all legs but vestigial posterior to about legs of $40^{\text {th }}$ segment.

Legs and sternum of 1 st pair of typical spirostreptid form (Figs 5-6). Coxae coalesced into a compact syncoxa; narrow sternal elements retained on both oral and aboral sides.

Gonopods as described under generic heading and illustrated in Figures 7-10.

Commentary: It has not been generally appreciated that the coxae of the two leg pairs of each segment/ring differ in size and shape, often dramatically, and this taxonomic potential therefore neglected. For convenience in reference, I suggest referring to those of the anterior pair as "procoxae" and of the posterior as "metacoxae", thus reserving the terms "anterior" and "posterior" for the general position of the legs in context of the entire body. An impression of Gilo in context of the entire Imatong range can be gained by reference to LANDSAT aerial photography (e.g., SatelliteViews.net, 2010). The vegetation at the elevation of Gilo (1900 m) has been characterized by Bussman (2006) as "supratropical montane forest".

\section{Genus Tibiozus Attems}

Tibiozus Attems 1950, Ann. Naturh. Mus. Wien, 57: 220. Monobasic with two subspecies.

Type species: Tibiozus robustus Attems, by original designation.

Tibiozus: Demange 1970, Bull. Inst. Fond. Afr. Noire, 32(A), 2: 377.

Tibiozus: Krabbe 1982, Abh. Naturwiss. Ver. Hamburg, NF 24: 224.

This genus was proposed by Count Attems in one of his last contributions (1950), to accommodate six species from Sudan, Madagascar, South Africa, and Brazil. The generic diagnosis specified a number of features of gonopod structure, most of them admitting of exceptions among the membership, and the widely dispersed distribution did not inspire confidence that this mélange was in actually a monophyletic genus. Attems expressed no opinion about the affinities of Tibiozus, beyond grouping it with Epistreptus and Mardonius in his key to spirostreptine genera. Two decades later the status of Tibiozus was addressed by J.-M. Demange (1970) in proposing a classification of the Spirostreptidae based on modifications of the gonopod telopodite. Because of having the telopodite flagelliform, with a triangular or digitiform process near its midlength, Tibiozus was grouped with the Neotropical genera Conchostreptus, Cladodeptus and Jeekelostreptus. In her generally 
comprehensive review of the family, Krabbe (1982) evaded a confrontation with this subject by simply omitting Tibiozus from her key to genera, and quoting fragments from Attems' original description in the generic and specific accounts without additional comment. In addition to the type species, this genus is known from Tibiozus sixi Demange (1975), described from Mweya, at the northern end of Lake Edward, Uganda. Regrettably, I cannot greatly improve on this deficient history of an interesting genus of fairly large spirostreptids apparently endemic to southern Sudan and adjacent Uganda. The male genitalia of its type species seem to contain both generalized and derived characters.

\section{Tibiozus robustus Attems}

Figures 1-6.

Tibiozus robustus robustus Attems 1950, Ann. Naturh. Mus. Wien, 57: 221, figs. 44-45. Male holotype (Naturh. Mus. Wien!), from "Gondokoro, Uganda”. [cf. commentary 3 below]

Tibiozus robustus pharaonicus Attems 1950, Ann. Naturh. Mus. Wien, 57: 223, figs. 46-47. Male holotype (Naturh. Mus. Wien!) from "Weissen Nil bei Heiligenkreuz". New Synonymy!

Material: Adult male (ZMUC) from the Talanga Forest, Imatong Mountains, East Equatoria Province, Sudan, 28 October 1980, F. Pagh Jensen leg. (Zool. Mus. Copenhagen Expedition). Male holotypes (NMW), of nominate robustus and the subspecies pharaonicus, cited above.

Synonymy: Only a few highly subjective characters were advanced to justify proposal of the subspecies T. r. pharaonicus. Personal comparison of the type specimens suggested to me that only normal phenotypic variation was evident, hardly justifying recognition of a subspecific taxon on the basis of two specimens only, possibly from the same locality.

Description: Attems' description of the type specimen is relatively complete and I take the occasion only to provide new drawings and small details derived from the Imatong specimen.

Ocellaria large, subreniform, medially acuminate, with ocelli in seven series as follows: $13-15-14-12-10-8-1=72$. Antennae (Fig. 11) short and robust, $2^{\text {nd }}$ article largest, $3^{\text {rd }}-5^{\text {th }}$ broadly triangular, wider than long, $6^{\text {th }}$ oval; $5^{\text {th }}$ and $6^{\text {th }}$ with distinct sensory pits on outer distal edge. Gnathochilarium (Fig. 12) of typical spirostreptid form, prebasal sclerite reduced to a small oval remnant on each side; distal enlarged sensory cone on each stipes surrounded by a field of soft white membrane (see Commentary 1 below). Collum (Fig. 13) not produced cephaloventrad, the three complete lateral striations lightly engraved. Sigilla (Fig. 14) relatively large, round to oval, in a single row with sporadic much smaller ones in a more posterior position. Posterior surface of metacoxae produced into low subtriangular lobes. Posterior coxal cavities (open or 


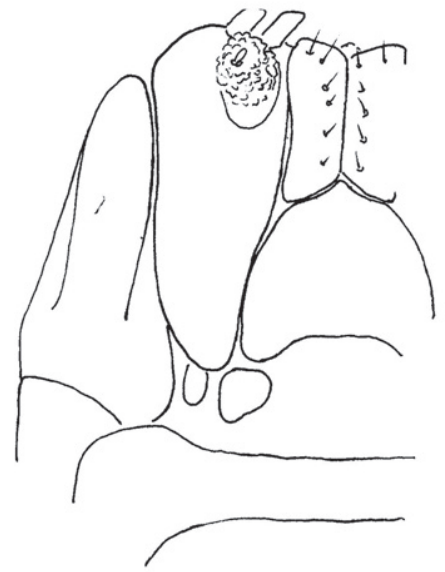

12
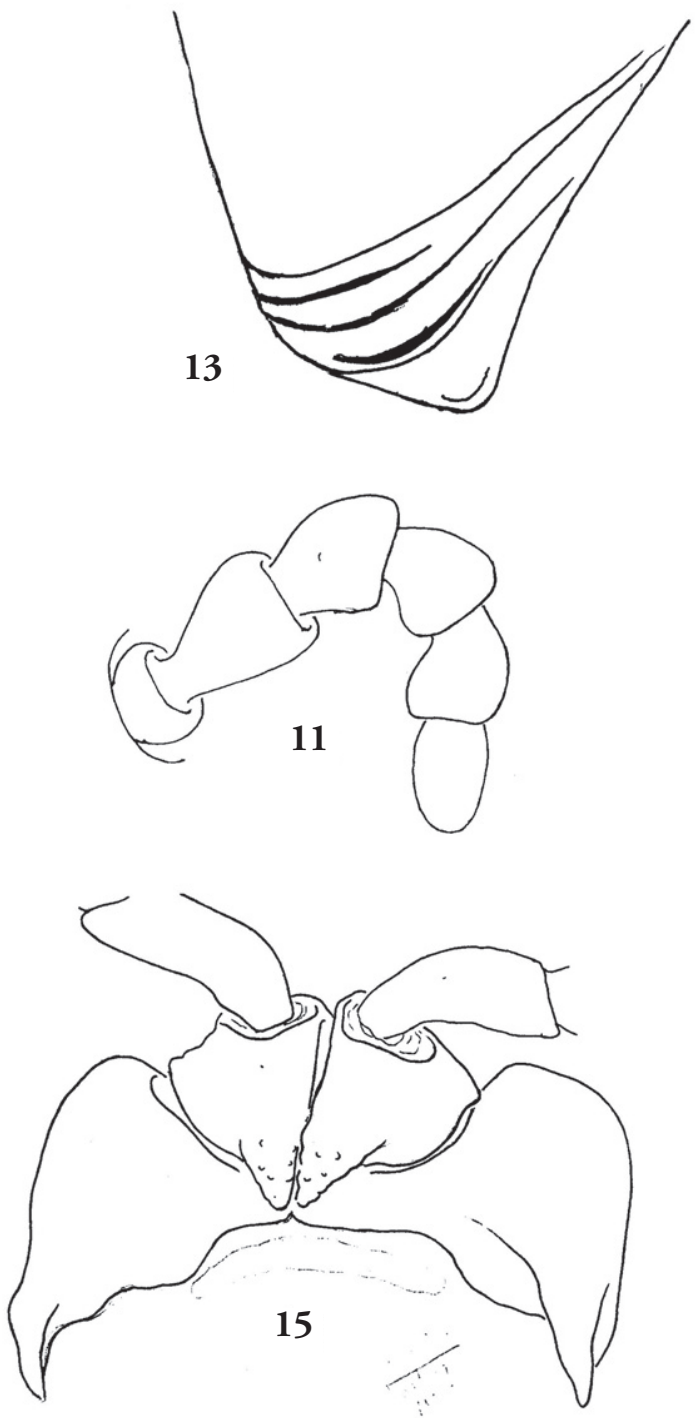

Figures 11-15. Tibiozus robustus (Attems), structural details. 11. Antenna. 12. Right side of gnathochilarium and mandible. 13. Right side of collum. 14. Small unit of midbody metazonum, internal surface (dark pigmentation not indicated), showing typical form of sigilla. 15. Syncoxa and prefemora of first pair of legs of male, oral aspect.

closed?). Coxosternum of $1^{\text {st }}$ legs of male (Fig. 15) notably lobed laterad to base of prefemora, processes of latter large and finely spiculate.

Gonopods (Figs 16-20) similar to those illustrated by Attems, notable in two respects: (1) the gonocoel is incompletely closed and the telopodite removeable without difficulty or structural damage (remarkable for any spirostreptoid!), leaving the prostatic stylet visible (Fig. 16), (2) torsion of the telopodite is "loose" (see Commentary 2 below). 


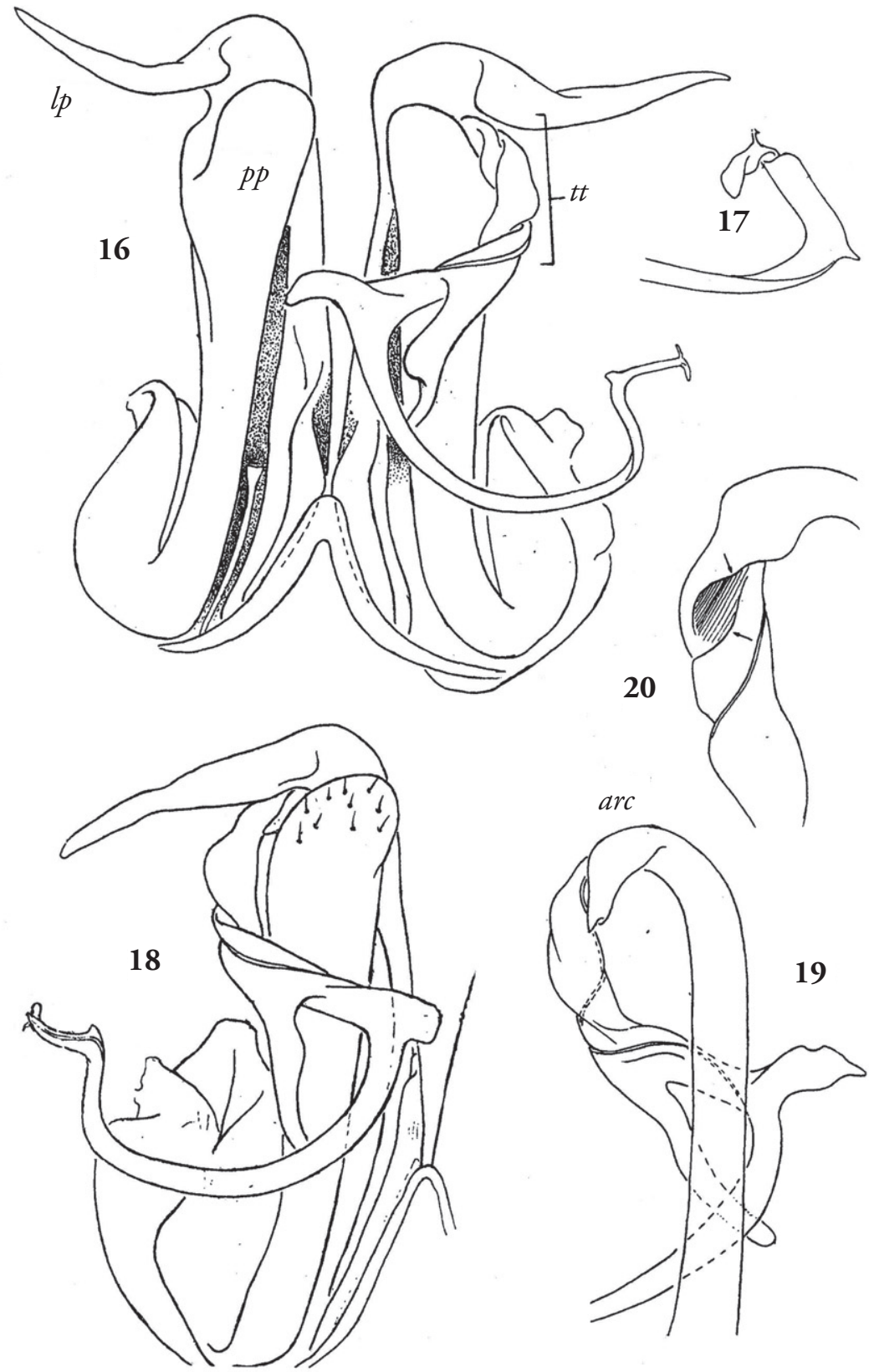

Figures 16-20. Tibiozus robustus, gonopod structure. 16. Gonopods of Imatong specimen, telopodite of left side removed showing open gonocoel (stippled) and prostatic stylet. 17. Apex of telopodite, greatly enlarged to show fine details. 18. Left gonopod of holotype, anterior aspect 19. Telopodite of right gonopod of holotype, posterior aspect. 20. Torsotope region of telopodite, specimen from Imatong, enlarged, to show loose configuration. Typically in spirostreptoids the two edges indicated by arrows are in close contact. Abbreviations: arc: arculus region of telopodite (= "grande courbure"); lp: lateral distal process of the metaplica; $p p$ : proplical fold; $t$ : torsotope region of telopodite (= "sinus de la rainure"). 
Commentary: (1) The conical, presumably sensory, megaseta of the stipes is typically placed on an oval, completely sclerotized convexity near the distal end. In the male specimen from Talanga, this accommodation is replaced by an area of soft white tissue that supports the cone; this is true for both sides and presumably not an abnormality. If confirmed in additional material, it is eligible to be regarded an autapomorphy for Tibiozus.

(2) In all of the spirostreptids known to me, the region at which the telopodite describes several $360^{\circ}$ rotations on its axis ("torsotope", = "sinus de la rainure" of Brolemann), has the form of a tight spiral the loops of which lie in direct contact. In Tibiozus robustus this region is clearly less compact, with open spaces visible between the opposed surface edges (Fig. 20). Perhaps this reflects retention of a less specialized condition, which would mandate one less complete rotation of the telopodite (as determined from a clay model subjected to controlled twisting). In any event, this condition seems unique to this genus, it is clearly shown in the gonopod of T. sixi Demange, 1975 (figure 1 in the cited paper).

(3) Gondokoro was a frontier settlement on the White Nile River a few kilometers downstream (north) of Juba, with the coordinates $4.54 \mathrm{~N}, 31.40 \mathrm{E}$; it no longer exists as a populated place and is not shown even on large-scale modern maps. However, during the $19^{\text {th }}$ Century it was an important trading center, and figures prominently in Alan Whitehead's The White Nile (1960). A contemporary (mid-1800s) illustration reproduced on page 137 of that book shows Gondokoro as a fortified cantonment beside the Nile, in a flat terrain with several low hills in the background. Although details about the source of the pharaonicus holotype are lacking (V. Stagl, in litt.), an Austrian Roman Catholic mission was established at Gondokoro as early as 1851, and this may have been the "Heiligenkreuz" on the label, and Dr. George Schweinfurth was a possible collector. Whether the material was actually collected at Gondokoro itself or brought in by a native from some regional hill forest is unknown.

\section{Acknowledgements}

My debt to Prof. Enghoff will be obvious; this paper is the result of his consideration of my interest in African spirostreptids. I am pleased also to thank Dr. Verena Stagl for access to collections under her care, and for later providing clerical details I had neglected to record at the time of my visit to the Naturhistorisches Musuem in 1997.

\section{References}

Attems, C. (1950) Über Spirostreptiden (Diplopoda). - Annalen des Naturhistorisches Museum in Wien 57: 179-257.

Bussmann, R. W. (2006) Vegetation zonation and nomenclature of African mountains - An overview. - Lyonia 11(1): 41-66. 
Demange, J.-M. (1970) Éléments d'une révision des Spirostreptidae. I. Étude de quelques caracterès taxonomiques des Spirostreptinae. - Bulletin de l'Institut Fondamental Afrique Noire 32(A) 2: 366-411.

Demange, J.-M. (1975) Nouvelle espèce du genre Tibiozus Attems récoltée en Ouganda. - Bull. Mus. Nat. Hist. Nat., (3) 291: 401-404.

Jeekel, C. A. W. (2006) Guyana Spirostreptidae, notes and descriptions. - Myriapod Memoranda 8: 27-44.

Krabbe, E. (1982) Systematik der Spirostreptidae (Diplopoda, Spirostreptomorpha). - Abhandlungen des Naturwissenschaftlichen Vereins in Hamburg (Neue Folge) 24: 1-475.

Mauriès, J.-P. (1976) Spirostreptides (Myriapoda-Diplopoda) de Guyane française. Description de deux genres nouveaux. Compléments aux diagnoses des types d'espèces sud-américaines. - Bulletin du Muséum National d'Histoire Naturelle (3) 333: 1257-1275.

Moorehead, A. (1960) The White Nile. Harper \& Brothers, New York, 385 pp. Sudan. http:// satelliteviews.net/sudan.htm. Accessed: 8 June 2010.

Verhoeff, K. W. (1943) Ueber einige diplopoden aus Minas Gerais (Brasilien). - Arquivos do Museu Nacional, Rio de Janeiro 37: 249-281. 


\title{
Treatise on Zoology - The Myriapoda, Volume 1
}

\author{
Edited by Alessandro Minelli
}

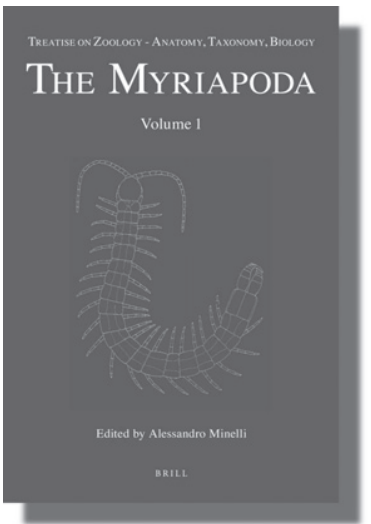

- February 2011

- ISBN 9789004156111

- Hardback (approx. 538 pp.)

- Treatise on Zoology - Anatomy, Taxonomy, Biology - The Myriapoda, 1

- List price: $€ 195.00$ / US\$277.00

Myriapods are the only major zoological groups for which a modern encyclopaedic treatment has never been produced. In particular, this was the single major gap in the largest zoological treatise of the XIX century (Grassé's Traité de Zoologie), whose publication has recently been stopped. 'The Myriapoda' fills that gap with an updated treatment in the English language. All aspects of biology of the four myriapod classes (about 15,000 species described to date) are covered, including external and internal morphology, physiology, reproduction, development, distribution, ecology, phylogeny and taxonomy. The work is thus a necessary complement for all institutional and personal libraries of researchers interested in Arthropoda or in soil biology.

\section{About the Editor}

Alessandro Minelli, Professor of Zoology at the University of Padova, is the author of Biological Systematics (Chapman \& Hall, 1993), The Development of Animal Form (Cambridge University Press, 2003), Perspectives in Animal Phylogeny and Evolution (Oxford University Press, 2009) and Forms of Becoming (Princeton University Press, 2009). His main research interest is, currently, the evolution of body architecture.

\section{brill.nl/tozm}

